\title{
Feudalism and Integration of the Native Peoples of Peru in the Worldwide Economy
}

\author{
Natividad Ferri Carreres
}

\section{Introduction}

The discovery of America opened the door to the first planetary global expansion. Near 1580, under the monarchy of Philippe II, the term "Universal Crown" was used to designate the worldwide Spanish territories which included Europe (The Netherlands, Portugal, and a part of Italy), America, Africa and Asia (Goa, Macao and the Philippines). ${ }^{1}$ The frontiers spread, the world became larger, and the ideas, laws, persons and commodities began to circulate. America was the center of this process. The silver went to Europe and to Asia from America, and the Chinese products, such as silk and porcelain, went to Europe through America. In the same way, the notion of local and native land changed. As a result of the exchange between autochthonous societies and Spain, Spanish institutions were adapted to the new context. In other words, a transculturation process started, a re-territorialization, where the European item was integrated into new lands, resulting in a neo-local model. ${ }^{2}$

The neo-local model, based on the feudal Spanish ideal, kept some aspects of Spanish feudalism, ${ }^{3}$ such as political and social coercion, and the social relations between the feudal lord and the serfs. In America, however, and particularly in Peru, the extractive activities of silver and gold, their commercialization and the profit motive created a new economic system, a "trade system" that favoured the emergence of new commercial markets and unequal exchange relations between the central European area and the peripheral American one. ${ }^{4}$

1 S. Gruzinski, Les quatre parties du monde: Histoire d'une mondialisation (Editions de la Martinière, 2004), 29-36.

2 Gruzinski, 81.

3 Concerning the feudalism-capitalism debate during the colonization, see the works of: R. Ruggiero, Les conquistadores (Flammarion, 1972), 68, 70-71, and S.J. Stern, "Feudalismo, capitalismo y sistema mundial en la perspectiva de América Latina," in Revista Mexicana de Sociología, vol. 49, n. 3, July-September 1987.

4 L. Martínez-Andrade, "La reconfiguración de la colonialidad del poder y la construcción del Estado-nación en América Latina," in Les cahiers de ALHIM (2008), 15.

(C) NATIVIDAD FERRI CARRERES, 2015 | DOI 10.1163/9789004282087_010

This is an open access chapter distributed under the terms of the prevailing CC-BY-NC License at the time of publication. 
The conquistadores were at the origin of this process. These first European colonizers achieved a feudal transfer, bringing with them all the imagery of the European knight and medieval lord, and projecting into America the medieval dream that was denied to them in Spain. During the Reconquista of Spain, the noble knights who fought against the Muslim enemy were rewarded for the heroic deeds performed by means of mercedes: the knight was placed at the head of a dominion, with the use of the lands given by the King and the authority over vassals bound to serve him and pay him tributes. The mercedes were given in appreciation of the services rendered, but at the same time served to strengthen the loyalty of the nobility to the King in the event of a conflict. How was the medieval machinery exported to America? What kind of legal support would allow the Crown and the conquistadores to appropriate lands and Indians and convert them into dominions and vassals? How did a feudal labor system create a capitalist form of production inserted in a global system?

\section{The Feudalization Process}

The figure of America's conquistador had little to do with the knights that recovered the Iberian territories from Muslim rule. The former came from a lineage of lower rank. Ruggiero Romano defines them as "poor devils, minor children of the nobility" whose main concern was to "become more worthy." They were not motivated by a desire for justice, nor heroic deeds, but by the obtainment of wealth and, above all, of the social prestige denied to them in Spain. Three impetuses defined the conquistador of the Indies: gold, glory and gospel. ${ }^{6}$ Gold, as the wealth they would never reach in Spain; glory, because the doors of the nobility and social prestige were closed for them on the old continent, while America offered the opportunity to ascend; and gospel, because they were responsible for expanding and perpetuating the spirit of crusade and evangelism that had culminated in the reconquest of the Kingdom of Granada.

America settled in the mind of the conquistador as the extension of Spain. Silvio Zavala admits that "the immigrant in America was not a new man, as he was linked by deep roots to his Western ancestors." ${ }^{7}$ Karen Spalding points out that "the dichotomy of Spanish society was also exported to America in the

5 R. Ruggiero, Les mécanismes de la conquête coloniale (Flamarion, 1972), 29-30.

6 I.A. Leonard, Los libros del conquistador (Fondo de cultura económica, 2006), 59.

7 S. Zavala, El mundo americano en la época colonial (Editorial Porrúa, S.A., México, 1967), 105. 
distinction between the nobles or members of the Church and the common... the distinction between those who served others (Indians) and those who were served (Spaniards)." 8 The author gives us the definition of colonial society according to Juan de Solórzano: "Así como cualquier república bien concertada requiere que sus ciudadanos se apliquen y repartan a diferentes oficios...así también...conviene y es necesario que, según la disposición de su estado, y naturaleza, unos sirvan, que son más aptos para el trabajo, y otros gobiernen y manden en quienes se halle más razón." ${ }^{\prime 9}$

Following the ideas of Spalding, the Indians became the dominated group in the colonial society, and therefore the only group that could be forced to perform servile tasks, in close relation to a low social rank. ${ }^{10}$ This state of servility was imposed upon the Indians firstly to justify a duty of justice over those defenseless people who could not be abandoned to themselves or to the tyrants that ruled them. ${ }^{11}$ Then, a detailed characterization of the Indian and his behavior was introduced from the ideology of contempt. It is worth transcribing the meticulous description made by Juan de Matienzo, judge at the Audiencia de Charcas around 1570, which leaves no doubt about the defects of Amerindian cultures and the benefits of being reformed by the Spaniards:

Los indios de cuantas naciones se han descubierto son pusilánimes y tímidos, que les viene de sus melancolías. Naturalmente, tiénense en menos de lo que se podrían tener. No piensan que merecen bien ni honra...Son muy crédulos, fáciles y mudables...Desde niños los enseñan a cargarse...Cuanta más fuerza tienen en el cuerpo tanto menos tienen de entendimiento...No trabajan más de para aquella que han menester por comer y beber aquella semana...Tienen habilidad en oficios mecánicos de todos géneros, de tal manera que hacen cuanto les mandan muy buenos labradores. Siendo de estas condiciones y costumbres les está mejor ser sujetos a españoles y gobernados por ellos que no por los Ingas...Según la ociosidad de los indios y su condición y el daño que de ella se sigue, es de entender que es bien inclinallos y compelellos al trabajo. ${ }^{12}$

$8 \quad$ K. Spalding, De indio a campesino (IEP, 1974), 151.

9 Spalding, cited by the author, 152.

10 Spalding, 168-169.

11 Prologue to B. De Las Casas, De Regia Potestate. O derecho de autodeterminación (CsIC, Madrid, 1984), 78.

12 Q. Aldea Vaquero, cited by the author in: El indio peruano y la defensa de sus derechos (csic, Madrid, 1993), 84-85. 
Once the Indians had been reduced to the category of "wheel horse," and once their necessity for the proper functioning of the colony had been justified, a way to control such a huge "flock" had to be found. The encomienda turned out to be the perfect institution for the exploitation of indigenous labour force, as well as for the payment of the services that the encomendero granted the Indians (indoctrination, protection, watching over their comfort); it also allowed the realization of the conquistadores' feudal dream: to obtain social privileges such as those that existed in Spain, through the donation of land, villas and vassals to the lord.

What was the encomienda? Juan de Solórzano gives us its legal definition in the 17th century, in his monumental work Política Indiana: "un derecho concedido por merced real a los beneméritos de las indias para percibir y cobrar para sí los tributos, de los indios...conforme a la ley de sucesión, con cargo de cuidar del bien de los indios en lo espiritual y temporal."13 The first Indian encomiendas were established in the West Indies, and later Cortés transplanted them to Nueva España: "Cada encomendero recibiría de Cortés un número determinado de indios, a los que gobernaría y de los que recibirían tributo en servicios personales y en especies."14

The Indian encomienda, as we have pointed out, consisted in the allocation of a plot of land and Indians by the conquistador, set up as a monarch, as a reward for the heroic deeds performed, although it did not confer the right of land ownership that was left in the hands of the King. But the encomendero did have a direct and personal control over the allocated Indians. This control showed up through the arbitrary imposition of work and duties that the Indians should perform. Therefore, the better or worse treatment of the Indians depended on the encomendero, underscoring the personal character of the institution during the first period..$^{15}$ In the first encomiendas, the Indians were considered as the support of the encomendero. The value of the encomendero, his prestige, was measured by the number of Indians he had. In fact, this period gave rise to the expression "feed" (dar de comer), which amounted to granting Indians, and not land or mines. ${ }^{16}$

13 J. de Solórzano Pereira, Política indiana (Biblioteca de Autores Españoles, Madrid, 1972) Tomo II, Libro III, cap. III, 21-22.

14 F.L. Jiménez Abollado, "La encomienda indiana, del sueño señorial a la legitimidad de la Corona: el centro de la Nueva España (1521-1570)," <www.adghn.org/confe/2005/encomienda .pdf>, Asociación de Diplomados en Genealogía, Heráldica y Nobiliaria, Madrid (2005).

15 J. Friede, "De la encomienda indiana a la propiedad territorial y su influencia sobre el mestizaje," in Anuario de Historia social y de la cultura, vol. 4, Universidad Nacional de Colombia (1969), 45 .

16 Friede, 41. 
The formula of the encomienda title at the dawn of the conquest read: "Por la presente encomiendo a vos...al cacique...con mas todos los caciques, capitanes e indios al dicho cacique sujetos; al cual y a los cuales mando que vos den y acudan con toda la comida y bastimentos y vestidos que hubiereis menester para vuestra casa y persona...Y con tanto que no les molestéis, y enseñéis las cosas de nuestra Santa Fe católica."17 However, the abuses committed during the early years caused a schism between advocates and opponents of this institution. Those who defended it employed solid arguments, which were religious (expansion of Christianity), political (to ensure the controll ${ }^{18}$ and settlement of the Spanish population, to satisfy the dominant minority), and economic (to increase the income of the King). With the encomienda, the entire colonial framework crystallized in its economic, fiscal, social, religious and political aspects. It was clear that the continuation of the colony depended largely on the survival of this institution. ${ }^{19}$ As Silvio Zavala says: "el arraigo de las encomiendas no podía suprimirse sin desorganizar la economía de las colonias.... La colonización reposaba económicamente sobre el trabajo de los indios. Si la corona insistía en limitar y destruir las vías que los españoles utilizaban para valerse de los indios, la colonización no podía subsistir."20

The history of the encomienda is a history of power transfers back and forth between monarchs and encomenderos. The chaos and the early absence of legal rules to regulate the encomienda were followed by the New Laws. ${ }^{21}$ These allowed the Crown to control this institution, but at the same time, showed the political impossibility of the monarchs to veto it: economic, financial and social interests were at stake at too long a distance. Crown and settlers fought a constant duel during three centuries to preserve their own interests: the encomenderos for the permanence of feudalism, and the Crown to put in place all the bureaucratic apparatus of the modern State. How could the Spanish feudal model articulate the Andean society in the worldwide economy of the time? The discovery and conquest introduced in America a dominant

17 Friede, 42.

18 B. De Las Casas, supra note 11, 81, the comendador of Sevilla, Juan de Zúñiga, wrote: "Su magestad debe con brevedad enviar contentamiento con mercedes a los conquistadores y pobladores de las indias conforme a sus méritos, de manera que no sea menester conquistar dos veces aquellas provincias, una de los indios y otra de los españoles."

19 K. Spalding, supra note 8, 159-160.

20 S. Zavala, La encomienda indiana (Editorial Porrúa, S.A, México, 1973), 97.

21 The New Laws, resulting from the Junta of Valladolid, suppressed the encomiendas, but these laws had never been applied. In this Junta, it was discussed the future of the Indias (new territories) and the future treatment of the Indios. Bartolomé de Las Casas argued that the Indios should be considered as free subjects of the Crown. 
minority, from the political and economic point of view, which reduced the majority native population to the status of dominated minority.

How did the germ of "europeization" emerge in the Incan society? Roman Ruggiero points out that the replacement of the original society by a European one of feudal type was easy in the case of the Incan Empire, due to its high level of organization, unlike what happened in the case of other nomadic and tribal peoples. ${ }^{22}$ But we cannot discard other circumstances such as epidemics, the superiority of Spanish weaponry, and the political divisions at the heart of the Incan Empire, which provided Pizarro with a mass of men who knew the area. What is clear is that the conquest was experienced by the indigenous population as a kind of "dispossession" and "chaos" of its traditional universe, embodied in the Emperor's death. ${ }^{23}$

Initially there was simply a transfer at the head of the State, from the Incan Emperor to the King of Spain. The Incan lands passed into the hands of the Spanish Crown, but the economic system based on the Indian labour force remained. The colonial society in Peru did not appear out of nowhere, but rather, as Nathan Wachtel points out quite rightly, was made from the survival of ancient structures within a new context. ${ }^{24}$ It is from the ruins of the Incan Empire that the colonial society established its foundations.

The Andean pre-colonial economy was based on a system of subsistence and barter, under a regime of reciprocity and redistribution of resources. No money was handled and exchanges were made in local markets. With the encomienda, the Spaniards dismantled this system, taking over all the resources and reshaping a regime of servitude different than the already existing one. The act of labour ceased to be a form of communion with the gods (the Indians provided labour force, cultivating the lands of the Emperor-God, and he rewarded them by redistributing the goods they needed for their livelihood), to become an unpaid imposition..$^{25}$

At this point, we can wonder how the emerging colonial society was inserted in the Spanish economic system. In the years $1560-70$ the Incan society had been completely dismantled, and the Viceroyalty of Peru was on the edge of chaos, due to epidemics, a declining population, revolts, perpetual encomiendas, and the abandonment of land. At the same time, the colonization of America emerged as a model of commercial exploitation, characterized by the exploitation and export of precious metals and other raw materials. America

\footnotetext{
22 R. Ruggiero, supra note $5,15$.

23 N. Watchel, La vision des vaincus (Gallimard, 1971), 54.

24 Watchel, 134.

25 E. Florescano, La clase obrera en la historia de México (UNAM, Siglo XXI editores, 1996), 32.
} 
was being shaped as the main supplier of these primary goods to Europe, obtained thanks to the work of the Indians.

In this context, the Indian encomienda could not conserve in America its original feudal status (production for local markets, subsistence economy). There, it had to be inserted within a capitalist economic system dominated by mining development and the investment of enormous sums of money from merchants and foreign bankers, and the emergence of large commercial transatlantic lines. ${ }^{26}$ The arrival of Viceroy Francisco de Toledo was to be decisive in the reorganization of the colonial society. As Juan M. Ossio states, his policy was "el corolario de sucesivos intentos por dejar sentir la presencia del Estado en contra del creciente poderío de la iniciativa privada de los conquistadores." 27 Toledo reorganized the chaotic pseudo-feudal society by laying the foundation of a colonial society of mercantile character, with the establishment of three institutions: the forced migration (the mita), the indigenous 'reductions', and the legislation of the tax collection by the Crown. ${ }^{28}$

The encomiend $a$ and the mita ${ }^{29}$ personified the extortion by the Spaniards in America. In the mid 17th century the commercial and agricultural demands increased, and as a consequence, so did the demand for workforce. The extraction of minerals increased as well, and international trade began. In this context, the mita (a coercive working system through the forced migration of the Indians) allowed the Crown to assume its economic needs, enlisting the Indian workers by force and distributing them in farming, mining and domestic work, ${ }^{30}$ in exchange for a wage stipulated between encomenderos that did not reach the Indians. Usually the mitayo Indian moved with members of his community to ensure its maintenance and reproduction. Thus, feeding costs were the responsibility of his community of origin, ${ }^{31}$ who took over the financing of the raw material extraction. As a result, the production costs for the Spaniards were insignificant.

26 S. Zavala, supra note $7,240-250$.

27 J.M. Ossio, Los indios del Perú (Editorial Mapfre, 1992), 171.

28 E. Tandeter, Coacción y mercado. La minería de la plata en el Potosi colonial (1692-1826) (Siglo XXI de España Editores, S.A., 2002), 39.

29 K. Spalding, supra note 8, 101-102: "Tómese la palabra mita utilizada para designar el turno de trabajo o el intercambio recíprocamente debido por los miembros de una comunidad, a sus jefes y al gobierno Inca, y posteriormente aplicada por los españoles al reclutamiento de mano de obra para trabajar en las minas y en otras empresas coloniales."

30 S. Zavala, Ensayos sobre la colonización española en América (Emecé editores, S.A., Buenos Aires, 1944), 161.

31 E. Tandeter, supra note $28,39$. 
Eventually, the payment of a salary to the Indians was accepted, and stipulated every year, ${ }^{32}$ during the first years in kind and later on in currency. As the Spaniards sold to the Indians products brought from Europe at a price that they could not afford, they forced them to sell back their workforce in other mines, in order to earn some money and avoid being in debt. Nathan Wachtel defines this situation as a proletarianization of the Indians, ${ }^{33}$ because the sums of money they earned did not allow them to generate a capital, as they had to use them to deal with debts and burdens imposed by the Spaniards. But, on the other hand, with the sale of European products to the Indians, the latter managed to enter the international market system, not only as producers, but also as consumers of European goods.

The new economy introduced by the Spaniards changed the Peruvian Indians, farmers and cattle breeders within a collective and communally supportive exploitation system, into proletarians for private exploitation or simple peasants relegated to the poorest and least productive lands. The Indians assumed their new role within the colony as a "pact of reciprocity," whereby the Crown guaranteed their possession of the land in exchange for their tribute and work at the mita. ${ }^{34}$ However, the need to recruit a lot of workforce for the mita led to the gathering of the Indians into easily manageable communities. Toledo described the model of the indigenous Incan communities: first the dispersion of the Indian population provoked by the encomiendas, then the grouping in villages, the reducciones, made in the Spaniards' image and likeness, but separated from them and keeping the rural Andean organization and a local authority. Ossio believes that "es en aquellas reducciones donde las modernas comunidades campesinas andinas encontraron su partida de nacimiento."35

According to Fernando Fuenzalida, the reducción was the most comprehensive instrument that allowed the germ of colonization to be spread:

La reducción fue la institución creada para satisfacer una serie de requerimientos, a varios niveles, no únicamente de tipo económico: a nivel económico, la organización de la población incaica en unidades fácilmente manejables capaces de proveer al país con mano de obra...

\footnotetext{
32 J. S. Stern, "Feudalismo, capitalismo y sistema mundial en la perspectiva de América Latina," Revista Mexicana de Sociología, vol. 49, n 3 3, 29-30.

33 N. Wachtel, supra note 23, 186.

34 E. Tandeter, supra note $28,42$.

35 J. Ossio, supra note $27,172$.
} 
A nivel político el mantenimiento de un campesinado libre cuya única lealtad esté dirigida a la corona.... a nivel religioso, la difusión de la religión $\mathrm{y}$ valores por los cuales la conquista fue realizada...A nivel social, el mantenimiento de fronteras netamente demarcadas entre los gobernantes coloniales y el campesino indígena sometido. ${ }^{36}$

These reducciones were at the origin of the indigenous smallholdings and the present communities. They were usually the less productive lands. In addition, they were intended for the usufruct and their sale was not allowed. At the same time, the Crown allowed the "compositions," some kind of deed of ownership given to the Spaniards who had occupied land without possessing the necessary titles. ${ }^{37}$ This process accelerated the formation of latifundia, farms or ranches.

\section{Colonial Heritage and Inclusion of Indigenous Peoples in Today's Global Economy}

In three centuries of Spanish colonization of Peru, Spain dislocated the Incan society, transferred its feudal society model, and adapted it to the new situation of commercial exploitation. Not only did colonization change the social, political and economic structures of Peru, it also transformed the Indians, "feudalizing" them first, and then turning them into a kind of proletarian, an agent of the emerging global trade. Nevertheless, the Indians were excluded of the free labour market, because they were constrained to work extracting and transporting the minerals without a salary.

With the passing of centuries, but especially after independence (1821), the gap between feudalism and capitalism became clearer and deeper: capitalism prevailed in coastal towns, populated mostly by creoles, heirs of the Spaniards, while the feudal regime was relegated to the mountains, the lands associated with the Indians. When the mineral extractive activities declined, the agricultural commercial activities had been developed in the coastal lands, with a free labor force, such as proletarian workers. At the same time, the traditional agriculture producing for the local market was located in the highlands, the Sierra, under the hacienda system where the production was based on servile relations. The political independence of Peru reinforced this situation, limiting the Indian participation to the global economy.

36 F. Fuenzalida, 'La comunidad tradicional', in El campesino en el Perú (IE P, 1970), 66.

37 J. Friede, supra note $15,53$. 


\section{The Cultural Lag ${ }^{38}$ in the Peruvian Dominant Class Excludes the Indians from the Global Economy}

Independence and Republic represent a hinge period to understand the current situation of the Indians in Peru. The independence revolution was not a movement of integration of the indigenous group. On the contrary, even if the criollos (Spanish descendents) promoted it and a distribution of land was ordered, it favored the landowning aristocracy of the colony which preserved its rights and properties intact.

José Carlos Mariátegui studied the feudal inheritance of the Peruvian Indians. ${ }^{39}$ In his work, "Siete ensayos de interpretación de la realidad peruana," he asserts that the Republic is a Peruvian and liberal regime as opposed to the Viceroyalty, which was a Spanish and feudal regime, ${ }^{40}$ and therefore the Republic "tiene deberes que no tenía el virreinato...Le tocaba elevar la condición del indio."41 Mariátegui accuses the Republic of feeding the backwardness of the Indians and sinking them into misery, when it broke the symbiosis that linked them to the land. According to the author, the land is the raison dêtre of the Indian, he "ha desposado la tierra," ${ }^{22}$ but the colony snatched it from him and the Republic has not restored it. Therefore, the Republic bears more responsibility for making the Indians lethargic, by stripping them permanently of the only material property that gives meaning to their existence.

The rural Peru during the 2oth century was dominated by the gamonal ${ }^{43}$ and the greater agricultural plantations owned by criollos or European immigrants who were often absent. The haciendas functioned by "remote control," 44 with a mass of servile indigenous population. Lords and serfs were in a feudal

38 W. F. Ogburn, Social change: with respect to culture and original nature (Oxford England, Delta Books 1966). Cultural lag is the notion that culture takes time to catch up with material innovations. This lag causes social and political conflicts.

39 J.C. Mariátegui, 7 ensayos de interpretación de la realidad peruana (Biblioteca Amauta, Lima, 1952).

40 Mariátegui's thesis about the feudal character of the colony can be arguable. Stern in his article 'Feudalismo, capitalismo y sistema mundial en la perspectiva de América Latina' puts us on guard regarding the trap of considering colonial economic exploitation solely from a feudal perspective.

41 J.C. Mariátegui, supra note 39, 37.

42 Mariátegui, 37.

43 Mariátegu, 43, Gamonal is a resistant and parasite Peruvian plant which grows inhibiting the growing the neighboring plants. This word was used since the 19th century to designate the landlords without colonial lineage which dispossessed the community's lands by illegal means.

H. Neira, Cuzco: Tierra y muerte (Populibros peruanos 1964), 115 . 
archaic context, living in an involution process ${ }^{45}$ until the agrarian reform promulgated in the second half of the 2oth century. During the first half of the century, the number of Indians working in one hacienda was an important item to estimate its value. As a result, during four centuries, the relationships between the landlords and the Indians had not changed significantly, the gamonal had only imitated the encomendero, and the Peruvian State took the place of the King of Spain.

However, between 1962 and 1964, the Indian peasants of the highlands of Cuzco and Puno claimed their rights and attempted to recover their lands from the haciendas. They organized peasant unions and reoccupied theirs lands, handling flags with this device: "Land or Death." This peasant mobilization pushed the State to elaborate programs of land reform which ended the feudal system in the highlands of Peru, and allowed the peasants to develop a consciousness of their collective force vis-à-vis the State and the others classes. Victor Villanueva considers that through this mobilization the peasant political level raised and the peasants showed that they were able to lead rational demands, organize their class struggle, and achieve their goals. ${ }^{46}$ In addition, the peasant mobilization reinforced the idea that education was essential to overcome poverty.

This mobilization, and the political measures taken by the military government between 1968 and 1975, created the conditions to integrate the "vanquished of the Spanish Conquest" to official Peru. However, neo-liberal waves arrived in Peru with Fujimori's government. The state mining companies were sold to multinational enterprises which acquired new land concessions to exploit silver, copper and gold, in exchange for the payment of a beholden or mining tax to the State. These precious metals are located in the highlands, in peasant community territories. They did not have any legal means to protect their lands when the Peruvian State decided to obtain high revenues to the detriment of the peasant's standard of living.

Yanacocha is a very good example of how foreign enterprises are working in the highlands nowadays. Located in Cajamarca region, north of Lima, this mine is the largest in South America. It was created in 1992, with the Newmont Mining Corporation of Denver as the major shareholder. The city has tripled its population and developed its infrastructure services, and has already received from this enterprise USD 812 million $^{47}$ as mining tax. As a result, $44 \%$ of the

\footnotetext{
$45 \quad$ Neira, 75 .

46 V. Villanueva, Hugo blanco y la rebelión campesina (librería editorial Juan Mejía Baca, Lima 1967), 178 .

47 Source: INEI.
} 
revenues of Cajamarca region come from this tax. These are unequally distributed among the villages of Cajamarca. In fact, near $80 \%$ of the inhabitants of Encañada, Sorocucho and Huasmin are living under the poverty threshold. ${ }^{48}$

Two years ago, Yanacocha proposed a new mining project in Cajamarca, specifically in Conga. This area possess near 6,00o hectares of land used for crop production and cattle feeding by the peasant communities. If the project is realized, four natural lakes would disappear and the Conga people should be removed from their lands and houses without any compensation. ${ }^{49}$ In addition, the neighboring water resources would have a high risk of being contaminated with cyanuric acid. This ecological catastrophe would be even more critical for the Indian population because mountains and lands are linked to their cultural believes.

\section{The Indian Struggle against the Onset of Ultra-Globalization and the Legal Measures to Protect Their Territories}

International legislation is increasingly concerned about the welfare and recognition of indigenous peoples. Concerning this legislation, I will mention the Convention 169 of the ILO (International Labor Organization) about the right of referendum, signed by Peru in 2007. The Convention has two basic postulates: respect for the culture, ways of life and traditional institutions of indigenous peoples; and referendum and effective participation of these peoples in decisions that concern them. ${ }^{50}$ As to the right of referendum, the Convention says in article 6: "Al practicar las disposiciones del presente Convenio, los gobernantes deberán...consultar a los pueblos interesados, mediante procedimientos apropiados, y en particular a través de las instituciones representativas." ${ }^{51}$ It accepts the importance of land for these cultures, recognizes the right of property and possession over the land they traditionally occupy, and requires governments to take appropriate legal measures for the fulfillment of this legal norm (article 14):

48 Source: INEI.

49 J. Abdelrahim, "La maldición de Atahualpa," in El País (19 February 2013): "Chaupe y su familia viven en el epicentro del terreno que Yanacocha ha adquirido para ejecutar el proyecto Conga...Jamás recibió un dólar por el agravio...De la noche a la mañana se enteraron de que, a cambio de nada, una minera estadunidense había era dueña de las tierras donde tiene su casa."

$5^{0}$ J. Jerjes Loayza, "Entre el progreso y el abuso: problemática social en torno a las tierras protegidas de las comunidades nativas en el Perú," in Astrolabio 7 (2011), 88.

$5^{1}$ ILo Convention 169 Indigenous and Tribal People 1989, <www.ilo.org/public/spanish/ region/ampro/lima/publ/conv-169/>, visited June 252013. 
1. Deberá reconocerse a los pueblos interesados el derecho de propiedad y de posesión que tradicionalmente ocupan...

2. Los gobiernos deberán tomar las medidas que sean necesarias para determinar las tierras que los pueblos interesados ocupan tradicionalmente y garantizar la protección efectiva de sus derechos de propiedad y posesión.

3. Deberán instituirse procedimientos adecuados en el marco del sistema jurídico nacional para solucionar las reivindicaciones de tierras formuladas por los pueblos interesados.

However, the Peruvian Congress waited until August 2011 to promulgate the Law of Prior Referendum, which allows the application of the Convention to safeguard these rights. ${ }^{52}$ Later on we will discuss the reasons for this delay.

On the other hand, the Peruvian Constitution is still reticent to recognize these communities. The Constitution of 1993 stipulates, in article 66, about natural resources that they are "patrimonio de la Nación." The State is sovereign in their exploitation. The right of property is recognized in article 70 of the Constitution, but subject to the interests of the State: "El derecho de propiedad es inviolable. El Estado lo garantiza. Se ejerce en armonía con el bien común y dentro de los límites de la ley. A nadie puede privarse de su propiedad sino exclusivamente por causa de seguridad nacional o necesidad pública." 53 What are these public needs referred to in the law? Would they be mainly economic interests?

The answer is probably yes. It is known that the greatest natural resources of the country are located in the territories occupied by indigenous peoples. Thanks to article 66 of the Constitution, natural resources are owned by the State, which is therefore sovereign to decide who will undertake the exploitation of such resources. ${ }^{54}$ Also under article 70, citing the need for public or common good, the State can 'rip' territories from indigenous peoples and grant their exploitation to private companies. Despite the fact that the international community has pointed out its interest for the protection of the natural territories of the Indian communities, the Peruvian laws depend on economic and political interests. The political measures taken by the last two presidents, Alán García and Ollanta Humala, reinforce this statement.

\footnotetext{
$5^{2}$ J. Jerjes Loayza, supra note 50, 89.

53 Constitución política del Perú de 1993, < www.tc.gob.pe/constitucion.pdf>, visited June25 2013 .

54 P. Castillo, "Marcos legales de acceso a la tierra, Caso Peruano," research not published (Lima, CEPES, 2010), 28.
} 
Alán García, in his second term, governed Peru between 2006 and 2011. In 2008, he promulgated some legal decrees in order to sign the TLC (Free Trade Agreement) with the USA. These decrees promote the oil extraction of the Amazon region through land sales to foreign companies. These measures permitted to sell $60 \%$ of the land of a region if $50 \%$ of the participants of the communal assemble, plus one, agreed to sell the land. ${ }^{55}$ These measures provoked a community revolt in Bagua, with 33 deaths. García did not make anything to promulgate the Law of Prior Referendum; instead, he adopted demagogical and anti-Indian positions pointing out the responsibility of the indigenous communities in keeping the underdevelopment of the forest region. In June 2009, he compared the Indians to the "Perro del Hortelano" (dog in the manger), that does not eat and does not let others eat. In other words, he blames the indigenous communities for the backwardness suffered by the country, by not wanting to take advantage of their lands and not allowing others to do so:

Hay millones de hectáreas para madera que están ociosas, otros millones de hectáreas que las comunidades y asociaciones no han cultivado, ni cultivarán...además cientos de depósitos minerales que no se pueden trabajar...Así pues, hay muchos recursos sin uso, que no son transables, que no reciben inversión y que no generan trabajo. Y todo ello por el tabú de ideologías superadas, por ociosidad, por indolencia o por la ley del perro del hortelano que reza: si no lo hago yo, que no lo haga nadie. ${ }^{56}$

He accuses the indigenous peoples of increasing the indebtedness of the country, because they do not want to exploit their own resources and prefer the country to spend money buying them from other countries:

Y contra el petróleo, han creado la figura del nativo selvático "no conectado"; es decir, desconocido pero presumible, por lo que millones de hectáreas no deben ser exploradas, y el petróleo peruano debe quedarse bajo tierra mientras se paga en el mundo us $\$ 90$ por cada barril. Es preferible para ellos que el Perú siga importando y empobreciéndose. ${ }^{57}$

In an interview with Alán García in 2009, the former President of Peru declared about the indigenous peoples: "Estas personas no tienen corona. Estas personas

55 B. Jiménez, "Los perros del hortelano muerden a Alain García" in El Mundo, 11 June 2009.

56 A. García Pérez, "El síndrome del perro del hortelano," in El Comercio (28 October 2007).

57 See note $35^{8}$. 
no son ciudadanos de primera clase...quien piensa de esa manera quiere llevarnos a la irracionalidad y al retroceso primitivo." 58 During the four years in power, García did not make any attempt to promulgate the Law of Prior Referendum which would authorize to apply the principles of the Agreement 169 of the ILO and the recognition of the right to referendum.

The coming to power of Ollanta Humala in 2011 marked a turning point in the back and forth between government and indigenous communities. When he was a candidate, he visited Cajamarca and promised to protect the rights of the peasant population. He asked the people during an electoral meeting: "There exist some lakes and it seems that they are for sale, do you want to sell the water? Because in the mining areas, the preliminary consultation was already done, but were you consulted about it? What is more important, water or gold? Because you do not eat nor drink gold, we drink water, our children drink water, and our cattle drinks water...Consequently, I promise you to respect the will of Bambamarca people concerning the mining issue."59

According to his promise, once Humala assumed the political power he promulgated the Law of Prior Referendum, pointing out his interest to establish a dialogue between the people and the investment companies' interests. In article 3 , it aims to open a space of exchange between the different parties, government and indigenous communities, so that all angles are evaluated and they can negotiate and set conditions: 60 "La finalidad de la consulta es alcanzar un acuerd o o consentimiento entre el Estado y los pueblos indígenas u originarios respecto a la medida legislativa o administrativa que les afecten directamente, a través de un dialogo intercultural, que garantice su inclusión en los procesos que les afecten directamente." 61

However, it seems that political interests are more important than those of the indigenous communities. The law promulgated has some ambiguities and gaps, beginning with the identification criteria of indigenous peoples. These criteria are: direct descent from populations originating from the national territory; lifestyles, spiritual and historical ties with the territory they traditionally use or occupy; cultural patterns, social institutions and customs, and way of

$5^{8}$ Interview with Alán García on 8 June 2009, <www.peru.com/noticias/portada2>, last visited on 25 June 2013 .

59 Discurso pronunciado por Ollanta Humala con motivo de su gira electoral en Bambamarca en 2011, <http://www.youtube.com/watch?v=LqRlpijJuP8>, visited on 15 September 2013.

6o J.M. Silva, “¿Qué viene después de la aprobación de la Ley de Consulta Previa?,” in $L a$ República (26 August 2011).

61 Law of Prior Referendum, in "Aquí el texto completo de la Ley de Consulta Previa, promulgada por el presidente Humala," in La República (6 September 2011). 
life different from other sectors of the national population (article 7 LCP) ${ }^{62}$ The problem is that a community that does not speak the indigenous language, or is composed mainly of a mestizo population, or does not descend directly from those pre-colonial communities, would not be included within this legal framework.

In Peru there are 13,885 peasant and native communities recognized and entitled, ${ }^{63}$ of which not all meet the identification criteria of the Law of Prior Referendum because they did not preserve their language or thousand-yearold traditions. The peasant communities of Cajamarca are in a vacuum legal situation. Today, the government of Humala has decided to exclude from the criteria of the law communities of the coast and mountains (incidentally those who have major mineral resources), under the pretext that they are peasant communities linked to urban activity and the service of the State, ${ }^{64}$ and therefore fall outside article 7 of the Law of Prior Referendum. Other ambiguity of this law is based on the fact that the decision resulting from the referendum does not constrain the government to change or suppress the project. This law permits the Indians to express their will, but does not warrant that it will be taken into account by the government.

Currently, the Cajamarca region, to the North of the country, is suffering once more from the speculation over its land, as at the time of the conquest. "Conga va," "Conga no va," are the battle cries of government and community members, respectively. What is the priority, gold or water? Capitalist development or respect for the ecological system? For the Indian communities, development comes from the use of water resources which become a mean of agricultural production and cattle breeding. Their life depends on these economical activities, on the harmonious equilibrium between man and nature.

In the last two years, the Indian communities of Cajamarca, knowing the lack of legal means to protect their rights, have organized to defend themselves. Their mobilization includes strikes, road blockades, and peasant rondas. ${ }^{65}$ These rondas have restored the old community networks of solidarity

62 Presidence of the Republic of Peru, <www.presidencia.gob.pe/ley-de-consulta-previa -promulgada-hoy-en-bagua $>$, visited on 25 June 2013.

63 Peruvian Ministry of the Environment, <sinia.minam.gob.pe/index.php?accion=verIndic ador\&idElementoInformacion=1017\&idformula $=92>$, visited on 25 June 2013.

64 Servicios en Comunicación Intercultural, $<$ servindi.org/actualidad/27622>, visited on 25 June 2013 .

65 G. Huamani, M. Moscoso, P. Urteaga, "Rondas campesinas de Cajamarca: la construcción de una alternativa." The peasant rondas (armed peasants) were born towards 1970, the northern region of Peru. At this time, the peasants conceived rondas as means to fight 
and collective work, organized through turns, and have impeded temporarily the realization of the mining project. The peasants showed a collective response vis-à-vis a private enterprise. ${ }^{66}$ The rondas accomplish the function of justice administration and keep social order in the communities. ${ }^{67}$ They seem to be the best organized response of the Indian communities.

Will progress be one day compatible with durable development? Will the Indians be able to participate actively in their development without losing their resources, vital for their survival? What will be the price to pay? Refuse progress and keep their resources, or participate in globalization as mining workers and give up their control? Here lies the huge trap in which these peoples have been caught: Peru is a country rich in mineral resources. The survival of many indigenous communities depends on the proper management of their exploitation. But many politicians believe that progress can only be brought through the liberal sale of these resources to large private companies, not worrying about whether these companies generate wealth for the communities they extract the minerals from, if they invest in infrastructure, schools or roads, or if they generate jobs in the region. One such example is that of the multinational mining company Southtern, which has invested USD 2 billion and only employs about 1,200 workers. Moreover, they buy machinery and equipment abroad and remit their revenues offshore. ${ }^{68}$ For decades, these economic interests have hindered the enactment of legal provisions favourable to the interests of indigenous communities. Here lies the explanation for the delay in the promulgation of the Law of Prior Referendum. A change of government was necessary in 2011 to modify the course of things.

\section{Conclusion}

"Indian" is a term that Europeans invented at the time of the conquest. It referred to anyone who had lived in America before the arrival of the Spaniards. The conquest converted the Indians into vassals of the Crown; the conquistadores converted them into servants, but the colony inserted them into the

against cattle robs and crop steals, a social illness in the rural, <http://www.cepes.org.pe/ debate/debateoo3/o3_articulo.pdf>, 68, visited on 10 October 2013.

66 J. Gitlitz, "Decadencia y supervivencia de las rondas campesinas del norte del Perú," <http://www.cepes.org.pe/debate/debate28/02_Articulo.pdf>, 24, visited on 10 October 2013 .

67 G. Huamani, M. Moscoso, P. Urteaga, supra note 65, 74-75.

68 J. Oscategui, “A otro perro con ese hueso," in La República (18 November 2007). 
capitalist economy, transforming them into proletarians. The independence and Republic, in its eagerness to erase racial differences involving the term "Indian," transformed them into peasants, cornering them in the mountains and hindering their access to the city. In colonial times, the Spaniards were in charge of the exploitation and marketing of natural resources. Today, the foreign multinational mining companies exploit and market those resources, covered by the Peruvian government.

In 1532, Pizarro captured Atahualpa in Cajamarca. The chronicles of the conquest say that, to obtain his freedom, the latter promised to fill two rooms of silver and one of gold, the size of the room in which he was imprisoned. ${ }^{69}$ The Spaniards agreed to the proposal, the Inca gave them the gold and silver, but he was executed anyway. This incident illustrates the immense greed of the Spaniards, which led them to undertake a race for the acquisition of rich lands with which to continue enriching the chests of the State. The social and economic gap caused during the colonial era was never overcome; on the contrary, it was accentuated during the republican period. The thirst for gold and silver and the struggle for land have not ceased. Apparently, gold and land continue today to be at the epicenter of social conflicts in Peru.

The new national and international legal framework shows that progress and tradition are not incompatible. Progress does not mean massive exploitation of resources, but bringing economic growth and facilitating the social inclusion of the more remote and isolated communities. The Law of Prior Referendum should not be understood as a penalty to the companies, but as an alternative to reach consensus. The law should allow assessing the shortcomings and the needs of the territories consulted in order to establish the viability of the commercial project. It is the key to the access to development and inclusion of the rural communities, and the safeguarding of the rights of these peoples.

There is a "shadow zone" that will have to be resolved, so that legislation concerning indigenous communities does not only mean a delay in the implementation of a commercial project and protests by indigenous communities, but the State recognition of a cultural background that belongs to them. For the first time, this law gives voice and vote to indigenous communities, while trying to reduce the endemic gap between countryside and city. Cajamarca, site of the Conga conflict, hides countless riches from the time of the Incas. The gold Atahualpa "sold" to the Spaniards in exchange for his release, in the 16th century, placed Peru on its way to exporting its precious metals without any benefit for the heirs of the vanquished of the conquest. Has the actual Peruvian government learned the lesson?

$69 \quad$ J. Abdelrahim, supra note 49. 


\section{Bibliography}

Abdelrahim, J. "La maldición de Atahualpa," in El País (19 February 2013).

De Las Casas, Bartolomé. De Regia Potestate. O derecho de autodeterminación, Consejo Superior de Investigaciones Científicas, Madrid, 1984.

Bauduin, Louis. L'Empire socialiste des Inka, Paris Institut d'Ethnologie, 1928.

Castillo, Pedro. "Marcos legales de acceso a la tierra, Caso Peruano." Investigación no publicada, Lima, CEPES (2010).

García Pérez Alán. "El síndrome del perro del hortelano," in El Comercio, 28 October 2007 .

Gitlitz, John. "Decadencia y supervivencia de las rondas campesinas del norte del Perú," Debate Agrario 28 (1998). <http://www.cepes.org.pe/debate/debate28/o2 _Articulo.pdf>.

Huamani, Giselle, Moscoso, Martin and Patricia Urteaga. "Rondas campesinas de Cajamarca: la construcción de una alternativa." <http://www.cepes.org.pe/debate/ debateoo3/03_articulo.pdf>.

ILo Convention 169 Indigenous and Tribal People 1989, Departamento de Normas Internacionales del Trabajo. Oficina Regional de oIT para América Latina y el Caribe./ ma. Edición actualizada: agosto de (1995).

Jerjes Loayza, Javier. "Entre el progreso y el abuso: problemática social en torno a las tierras protegidas de las comunidades nativas en el Perú," Astrolabio 7 (2011).

Mariategui, José Carlos. 7 ensayos de interpretación de la realidad peruana, Biblioteca Amauta, Lima, $195^{2}$.

Martínez-Andrade, Luis, "La reconfiguración de la colonialidad del poder y la construcción del Estado-nación en América Latina," Les cahiers de ALHIM, 2008.

Martínez, Héctor. "Evolución de la propiedad territorial en el Perú," Journal of InterAmerican Studies, Vol. 5, No. 4 (Oct., 1963): 437-450.

Neira, Hugo. Cuzco: Tierra y muerte, Populibros peruanos, 1964.

Oscategui, José. "A otro perro con ese hueso," in La República, 18 November 2007.

Ossio, Juan M. Los indios del Perú, Editorial Mapfre, 1995.

Ruggiero, Romano. Les mécanismes de la conquête coloniale, Flamarion, 1972.

Silva, J.M. “¿Qué viene después de la aprobación de la Ley de Consulta Previa?,” in La República, August 2011.

Spalding, Karen. De indio a campesino, IE P, 1974.

Villanueva, Víctor. Hugo blanco y la rebelión campesina (librería editorial Juan Mejía Baca, Lima 1967).

Wachtel, Nathan. La vision des vaincus, Gallimard, 1971.

Zavala, Silvio. La encomienda indiana, Editorial Porrúa, S.A, México, 1973; Ensayos sobre la colonización española en América, Emecé editores, S.A, Buenos Aires, 1944; El mundo americano en la época colonial, Edit. Porrúa, S.A, México, 1967. 